Diabetologia 8, 250-259 (1972)

(C) by Springer-Verlag 1972

\title{
Immunohistologic Investigations of Human Insulinomas
}

\author{
R. Arnold, U. Deuticke, H. Frerichs and W. Creutzfeldt \\ Department of Medicine Division of Gastroenterology and Metabolism University of Goettingen, W.-Germany
}

Received: February 25, 1972, accepted: April 28, 1972

Summary. 14 insulinomas were examined immuno. histologically using the peroxidase labelled antibody method. 8 tumours were investigated immediately after extirpation. 7 of these reacted with insulin and porcineC-peptide antisera but not with glucagon antiserum. Only a B-cell carcinoma with an unusually low insulin concen.tration was negative. One year after embedding in paraffin the immunohistologic reaction with insulin antiserum had markedly decreased in the tumours; however, not in the islet of the adjacent pancreas. From 6 patients 1 to 4 years old paraffin-embedded material of the tumour and the normal pancreas was available. In this group 4 tumours with an elevated insulin concentration reacted immunohistologically only weakly with an insulin antiserum and two tumours (one with high and one with low insulin concentration were immunohistologically negative, while the islets of the adjacent panceas of all six cases showed a strong reaction. Thus the immunohistilogic reaction of insulin in B-cell tumours but not in normal islets depends on the time elapsed between the paraffin embedding and the examination. Only tumours fixed in Bouin's fluid but not in Karnovsky's solution gave a positive immunohistologie reaction, while the islets of the adjacent pancreas reacted positively also after fixation in Karnovsky's solution. These findings suggest differences between the normal and the tumour insulin. A correlation between aldehyde-thionin stain and immunohistology indicates the superiority of immunohistology in identifying insulin producing tumour cells.

\section{Investigations immunohistologiques des insulinomes humains \\ Résumé. 14 insulinomes ont été soumis à un examen} immunohistologique à l'aide de la méthode de l'anticorps marqué à la peroxydase. 8 tumeurs ont été étudiées immédiatement après leur extirpation. 7 d'entre elles réagissaient avec les sérums anti-insuline et anti-porcineC-peptide, mais non avec le sérum anti-glucagon. Un seul carcinome à cellules $B$ avec un contenu en insuline in. habituellement bas, a été négatif. Un an après l'inclusion dans la paraffine, la réaction immunohistologique avec le sérum anti-insuline avait nettement diminué dans les tumeurs, mais non dans les îlots du pancréas adjacent. Chez 6 patients, on disposait de fragments de la tumeur et du pancréas normal inclus dans la paraffine depuis 1 à 4 ans. Dans ce groupe, 4 tumeurs avec un contenu ólevé en insuline, n'avaient qu'une faible réaction immunohistologique avec un sérum antiinsuline, et deux tumeurs (l'une avec un contenu élevé en insuline, l'autre avec un contenu faible) ont eu une réaction immunohistologique négative, tandis que les îlots du pancréas adjacent réagissaient fortement dans les six cas. Donc, la réaction immunohistologique de l'insuline dans les tumeurs à cellules B, mais non dans les ̂̂lots normaux, dépend du temps écoulé entre l'inclusion dans la parafffne et le moment où elles sont examinées. Seules les tumours fixées dans du liquide de Bouin, mais non dans la solution de Karnovsky, ont ou une réaction immunohistologique positive, tandis que les îlots du pancréas adjacent réagissaient positivement après fixation dans la solution de Karnovsky. Ces résultats suggèrent qu'il existe des différences entre l'insuline du pancréas normal et l'insuline des tumeurs. Une comparaison entre la coloration à l'aldéhyde-thionine et l'immunohistologie indique la supériorité de l'immunohistologie dans l'identification des cellules tumorales produisant de l'insuline.

Zusammenfassung. 14 insulinproduzierende Tumoren wurden mittels Peroxydase-markierter Antikörper immunhistologisch untersucht. 8 Tumoren gelangten unmittelbar postoperativ zur Untersuchung. Hiervon ließen sich 7 mit einem Antiserum gegen Insulin und Schweine-C-Peptid, nicht aber mit einem Antiserum gegen Glucagon anfärben. Dagegen reagierte ein B-Zellcarcinom mit einer sehr niedrigen Insulinkonzentration mit keinem dieser Seren. Bereits ein Jahr nach der Einbettung in Paraffin ließ die Anfärbbarkeit dieser Tumoren mit einem Antiinsulinserum deutlich nach, während die Inseln des umgebenden normalen Pankreas mit dem gleichen Serum unverändert stark reagierten. - Von 6 weiteren Inseladenomen standen außerdem 1-4 Jahre altes paraffineingebettetes Tumor- und Pankreasgewebe zur Verfügung. 4 dieser Tumoren hatten eine erhöhte Insulinkonzentration, reagierten immunhistologisch jedoch mit einem Antiinsulinserum nur schwach. Die beiden rest. lichen Tumoren - einer mit einer hohen, der andere mit einer niedrigen Insulinkonzentration - verhielten sich immunhistologisch negativ. Im Gegensatz zu den Tumoren ließen sich die Inseln des umgebenden Pankreas sämtlicher 6 Fälle mit einem Insulinantiserum gut anfärben. Somit scheint der erfolgreiche immunhistologische Nachweis von Insulin in insulinproduzierenden Tumoren von der Dauer der Einbettung des Tumormaterials in Paraffin abzuhängen. Das Insulin in den Pankreasinseln unterliegt dagegen diesem ,Alterungseffekt" nicht. - TumorInsulin läßt sich nur in Bouin-fixiertem, nicht aber in Karnovsky-fixiertem Gewebe immunhistologisch nachweisen, während das Insulin des normalen Pankreas auch nach Karnovsky-Fixation immunhistologisch nachwoisbar ist. Die Befunde sprechen für Unterschiede zwischen normalem pankreatischen und Tumor-Insulin. - Die Färbung der B-Zellen von Tumoren mit Aldehyd-Thionin gelingt seltener als der immunhistologische Nachweis von Insulin in diesen Zellen. Die immunhistologische Untersuchung ist daher zur Identifizierung von B-Zelltumoren. den üblichen spezifischen Färbungen überlegen.'

Key words: Insulinoma, immunohistologic investigation of B-cell tumours, peroxidase labelled antibodies, insulin and C-peptide in B-cells, insulin concentration of insulinomas, difference between insulin in normal and tumour B-cells. 
The reports on immunohistologic investigations of human B-cell tumours are contradictory. Only Breustedt and Kracht [2] using fluorescein labelled insulin antibodies succeeded in demonstrating insulin in 3 B-cell adenomas. However, the majority of the investigators demonstrated insulin only in the islets of the normal pancreas but not in B-cell adenomas or B-cell carcinomas $[4,9,10,14,19]$. These authors concluded that the structure of tumour insulin differs from the structure of normal insulin. This explanation seems unsatisfactory, because insulin from tumour tissue reacts, like pancreatic insulin, radioimmunochemically with an insulin antibody. Studies on the amino acid composition of polypeptide segments of the $A$ and $B$ chain of insulin extracted from several B-cell tumours resulted in no differences between the amino acid sequence of normal human insulin and tumour insulin [11].

In this paper the results of immunohistologic investigations on 14 insulin-producing tumours of the human pancreas will be reported. The B-cells of all tumours reacted with a peroxidase labelled insulin antiserum if the insulin concentration of the tissue was elevated. Some findings support the suggestion of immunological differences between normal pancreatic and tumour insulin.

\section{Material and Methods}

14 insulinomas were examined by routine histologic, immunohistologic and biochemical techniques. Preoperatively, all cases were characterized by low fasting blood glucose levels and marked hypoglycaemia during prolonged fasting. Most of them showed elevated fasting insulin levels and excessive plasma insulin concentrations after challenge with glucose, glucagon and tolbutamide.

\section{Preparation of antibodies}

a) Anti-insulin serum (total binding capacity 1.0 to $2.0 \mathrm{mU} / \mu \mathrm{l}$ ) was prepared in guinea-pigs by injection of solutions of crystalline porcine insulin emulsified in complete Freund adjuvant.

b) Anti-C-peptide serum was prepared in rabbits by injection of synthetic porcine-C-peptide without adjuvant. The antibody did not cross react radioimmunochemically with human insulin.

c) Anti-glucagon serum was prepared in rabbits by injection of crystalline beef-pork-glucagon (Eli Lilly, Indianapolis, USA), emulsified in complete Freund adjurant.

d) Anti-guinea-pig- $\gamma$-globulin from rabbit was purchased by Behringwerke AG, Marburg.

e) Anti-rabbit- $\gamma$-globulin from sheep was elicited by repeatedly immunizing a sheep with immunoelectrophoretically pure IgG from rabbits.

\section{Preparation of conjugates}

The $\gamma$-globulin fractions of the anti-guinea-pig serum from rabbit and of the anti-rabbit- $\gamma$-globulin from sheep was labelled with horseradish peroxidase as described by Nakane and Pierce $[15,16]$.

\section{Immunohistology}

7 B-cell adenomas and 1 B-cell carcinoma were studied immunohistologically immediately after extirpation of the tumours, whereas in the case of the other 6 B-cell adenomas paraffin blocks of preserved material were examined 1 to 5 years after extirpation.

Tissue samples of the tumours and the adjacent pancreas of cases studied immediately after extirpation were fixed for 45 to $90 \mathrm{~min}$ in Bouin's fluid. In order to prove the influence of duration of fixation, samples of one tumour (case 14 of Table 1) were fixed once for $60 \mathrm{~min}$, and once for $11 \mathrm{~h}$, in Bouin's fluid. In order to prove the influence of the kind of fixative, samples of 3 adenomas as well as of the adjacent pancreas were fixed also in Karnorsky's fixative [7]. Samples of tumours studied immunohistologically 1 to 4 years after extirpation were fixed in Bouin's fluid 3 to $6 \mathrm{~h}$ according to the size of the samples.

Tissue samples were then dehydrated in alcohol, cleared in xylene and embedded in paraffin.

For demonstrating insulin, C-peptide and glucagon the indirect technique according to Weller and Coons [26] was used. 1/20 diluted anti-insulin serum from guinea-pig was placed on $3 \mu$ thick sections for $30 \mathrm{~min}$. Parallel sections were incubated with equally diluted rabbit anti-C-peptide serum, rabbit anti-glucagon serum, normal guinea-pig serum and normal rabbit serum. After washing in phosphate buffered saline the sections previously treated with guinea-pig sera were subsequently incubated for $30 \mathrm{~min}$ in $1 / 20$ diluted peroxidase labelled anti-guinea-pig- $\gamma$-globulin from rabbit. Sections previously treated with rabbit sera were incubated in $1 / 20$ diluted peroxidase labelled antirabbit- $\gamma$-globulin from sheep. The peroxidase reaction was obtained by incubating the sections for $30 \mathrm{~min}$ in a benzidine solution according to a method described by Graham and Karnorsky [5]. After rinsing in aqua bidest., the sections were postfixed in $1 \%$ osmium tetraoxide, dehydrated in alcohol, cleared in xylene and embedded in DPX.

\section{Histology}

Sections of all adenomas and of the adjacent pancreas were stained with aldehyde-thionin according to the method described by Paget [18].

\section{Tissue extraction}

Immunochemical reacting insulin (IRI) was extracted from pancreas and tumour tissue with acidethanol and determined in the neutralized extracts 
using a back titration procedure [12] with guinea-pig anti-porcine insulin serum as the antibody.

\section{Results}

The biochemical, histologic and immunohistologic results of the 14 investigated B-cell tumours are compiled in Table 1. The tumours are listed chronologically according to the date of operation. With the exception of tumours 1,8,11 and 12 the IRI concentration of the tumours was higher than the IRI concentration of the adjacent pancreas. 10 tumours were aldehyde-thionin
With an antibody against crystalline porcine $\mathrm{C}$ peptide the B-cells of the tumours of the cases 7 to 11 , 13 and 14 and the B-cells of the islets of the adjacent pancreas of these cases reacted similarly as with an insulin antibody.

The duration of fixation in Bouin's fluid did not influence the reaction (Table 2). After fixation in Karnovsky's fixative, insulin could be demonstrated only in the normal pancreas, but not in the tumour tissue (Table 2).

Fig. 1 a shows the typical immunohistologic aspect of insulin in a normal human islet, Fig. $1 \mathrm{~b}$ its negative control. The positively reacting cells have a dark

Table 1. Insulin concentration, aldehyde-thionin staining and immunohistologic demonstration of insulin in $14 B$-cell

positive, 4 tumours were aldehyde-thionin negative. There was no correlation between the IRI concentration of the tumours and the aldehyde-thionin staining. Negative or weak aldehyde-thionin staining occurred not only in tumours containing very small amounts of IRI, but also in tumours with an elevated IRI concentration. Immunohistologically, insulin could be demonstrated in all B-cell tumours except the cases 1,5 and 10 . The immunohistologic reaction product was strong in the tumours 7 to 11,13 and 14. The tumours 7 to 14 were investigated immediately after extirpation. However, the reaction was rather faint in the tumours 2,3,4 and 6 . From the cases 1 to 6 tumour material was investigated immunohistologically for the first time 1 to 4 years after the embedding.
Table 2. Infuence of the fixation on the immunohistologic demonstration of insulin and $C$-peptide in the normal pancreas and in $B$-cell tumours of four patients

\begin{tabular}{llll}
\hline & \multicolumn{2}{l}{ Fixative } & \\
\cline { 2 - 4 } & Bouin & & Karnovsky \\
\cline { 2 - 4 } & $10 \mathrm{~min}$ & $\mathbf{1 1 \mathrm { h }}$ & $4 \mathrm{~h}$ \\
\hline tumour & ++ & ++ & $\varnothing$ \\
pancreas & ++ & ++ & ++ \\
\hline
\end{tabular}

brown colour, the nucleus being unstained. In Fig. $1 \mathrm{c}$ a parallel section was incubated with a C-peptide antibody. The same cells as in Fig. 1a are stained. In a further parallel section treated with an anti-glucagon 
serum different cells show a positive peroxidase reaction (Fig. 1d).

Fig. $2 \mathrm{a}$ is a typical example of the immunohistologic demonstration of insulin in a B-cell adenoma investigated immediately after extirpation (case 8 of Table 1). Compared with the negative control (Fig. 2 b) all tumour cells show a strongly positive reaction bodies none of the insulinomas listed in Table 1 reacted positively, while some cells of the islets of the adjacent pancreas always reacted positively.

After one year, the immunohistologic demonstration of insulin and C-peptide was markedly reduced in the tumours of cases $7,8,9$ and 10 , while the adjacent pancreas continued to show a strong reaction
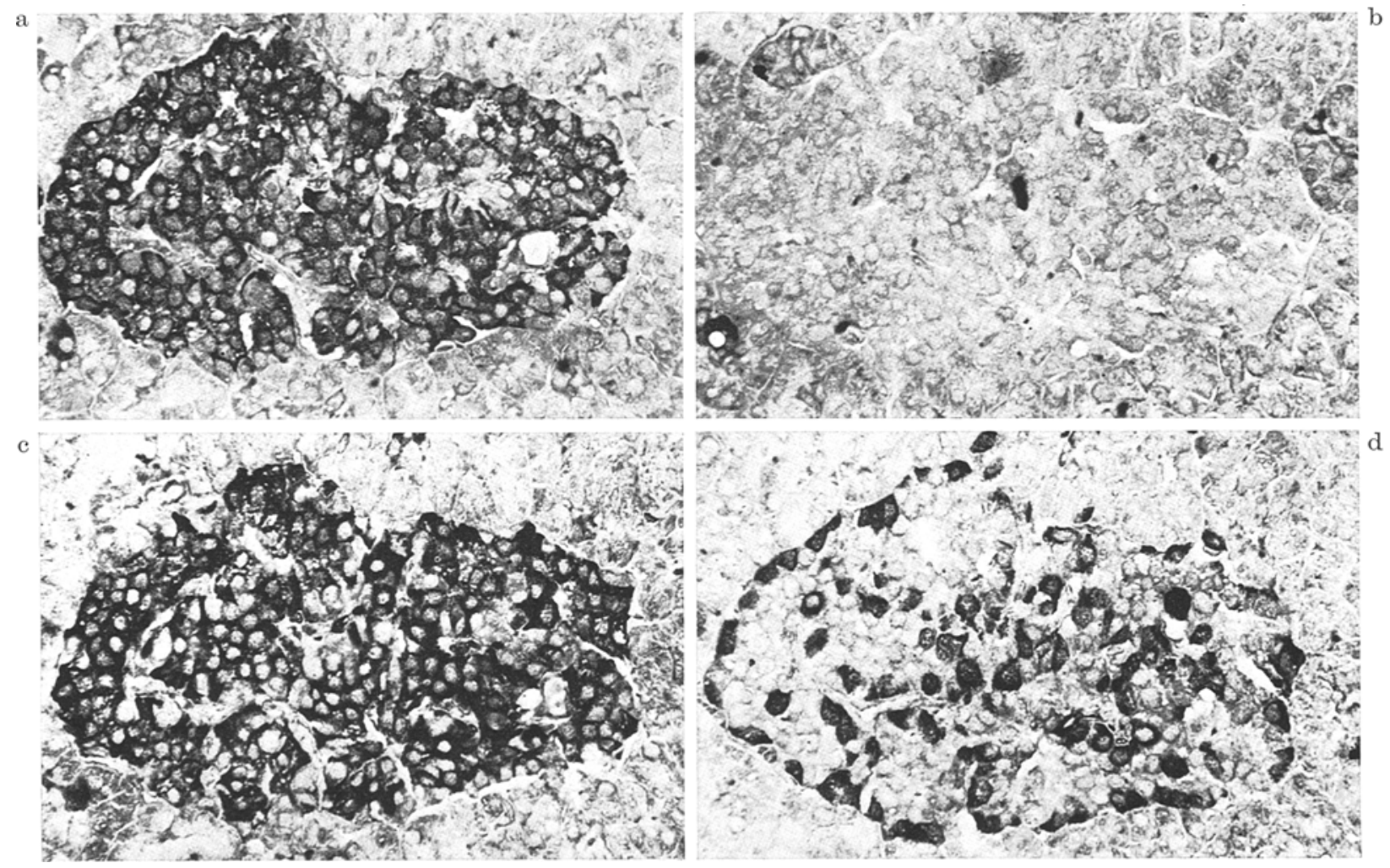

Fig. 1. Normal pancreatic tissue with a large islet, fixed in Bouin's fluid, embedded in paraffin. a) Incubation with $1 / 20$ diluted anti-insulin serum; after washing incubation with $1 / 20$ diluted peroxidase labelled anti-guinea-pig- $\gamma-$ globulin from rabbit. The islet shows numerous darkly stained insulin-containing cells. Magnification $x 400$. b) Parallel control section to a). Incubation with 1/20 diluted anti-guinea-pig serum followed by $1 / 20$ diluted peroxidase labelled anti-guinea-pig- $\gamma$-globulin from rabbit. No specific stain. Magnification $\times 400$. c) Parallel section to a). Incubation with 1/20 diluted anti-C-peptide serum from rabbit followed by 1/20 diluted peroxidase labelled anti-rabbit- $\gamma$-globulin from sheep. Compared with a) the same cells are stained. Magnification $\times 400$. d) Parallel section to $\mathrm{c}$ ). Incubation with $1 / 20$ diluted anti-glucagon serum from rabbit followed by $1 / 20$ diluted peroxidase labelled

anti-rabbit- $\gamma$-globulin from sheep. Compared with a) and c) different cells react positively. Magnification $\times 400$

product. A similar reaction is seen in a section of the same tumour after treatment with a C-peptide antibody (Fig. 2c).

Fig. 3 demonstrates the different reaction in the tumour of case 13 of Table 1. Compared with Fig. 2a only few tumour cells show a strongly dark brown reaction product, whereas the majority of the cells remains unstained. The same result can be achieved in a parallel section incubated with a C-peptide antibody. The IRI concentration of this tumour was low. Only one B-cell adenoma (case 10 of Table 1) showed a stronger C-peptide than insulin reaction (Fig. 4a, b). All the other B-cell tumours listed in Table 1 show identical staining behaviour after treatment with an insulin or C-peptide antiserum. With glucagon anti- product after incubation with an insulin or C-peptide antiserum. In cases 11 and 13 half a year after operation the staining intensity was still unchanged.

Fig. 5a demonstrates the immunohistologic reaction of a B-cell adenoma (case 8 of Table 1) one year after extirpation. Only a faint reaction product is visible compared with Fig. 2 a. In contrast, Fig. 5 b shows a normal islet of the adjacent pancreas investigated one year after the extirpation. The intensity of the reaction did not change.

Fig. 6 a demonstrates the weak reaction in a B-cell adenoma characterized by a high IRI concentration if studied 4 years after extirpation of the tumour. However, in pancreatic tissue of the same case embedded in paraffin 4 years ago the normal islets continued to 

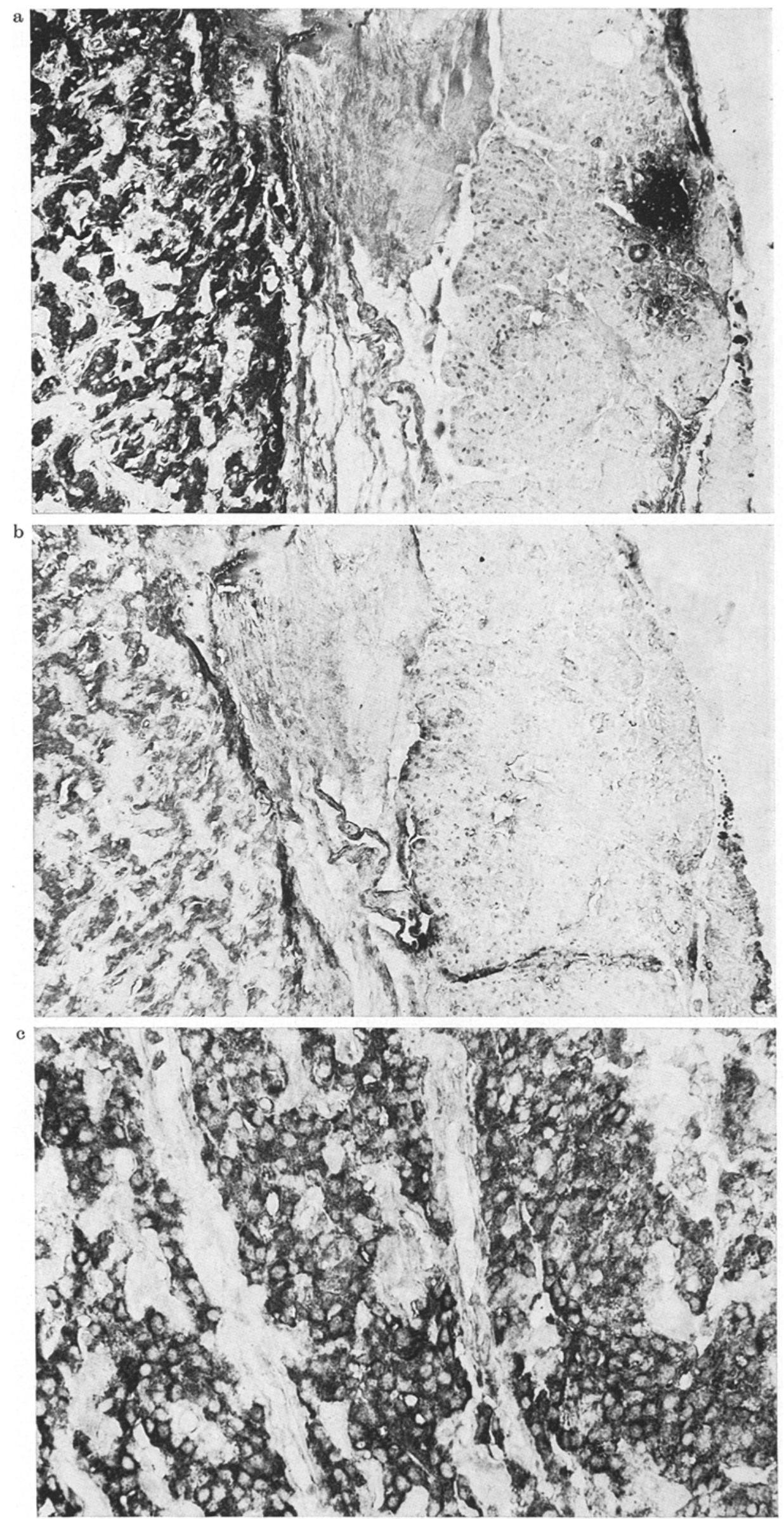

Fig. 2. a) Immunohistologic demonstration of insulin in a B-cell adenoma (case 8 of Table 1). Technique as in Fig. 1. Numerous insulincontaining tumour cells are seen on the left hand side, a normal islet in the adjacent pancreas is seen on the right hand side. Magnification $\times$ 160.

b) Control section to a).

Magnification $\times 160$.

c) The same tumour stained with an anti-C-peptide serum. Magnification $\times 400$ 


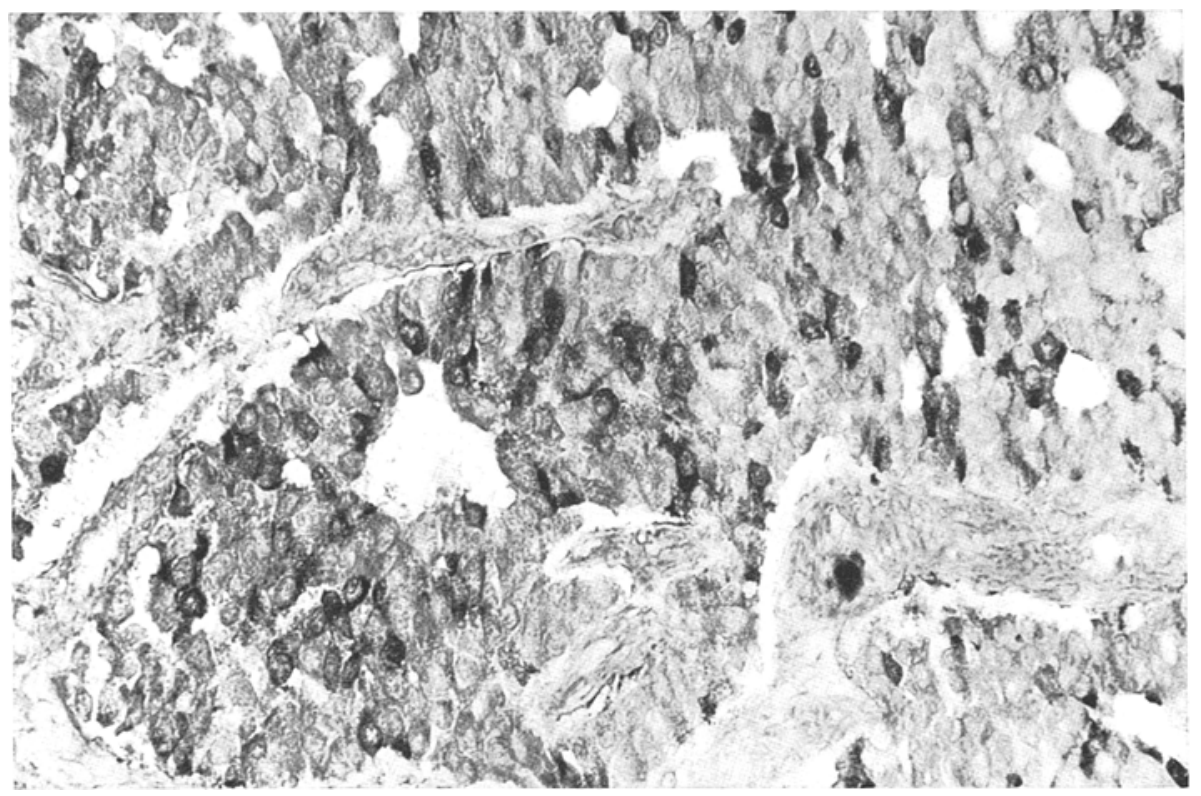

Fig. 3. Only few B-cells react in this tumour with an anti-insulin serum compared with Fig. 2 a, whereas the majority of the cells remain unstained (case 13 of Table 1 ). Magnification $\times 400$

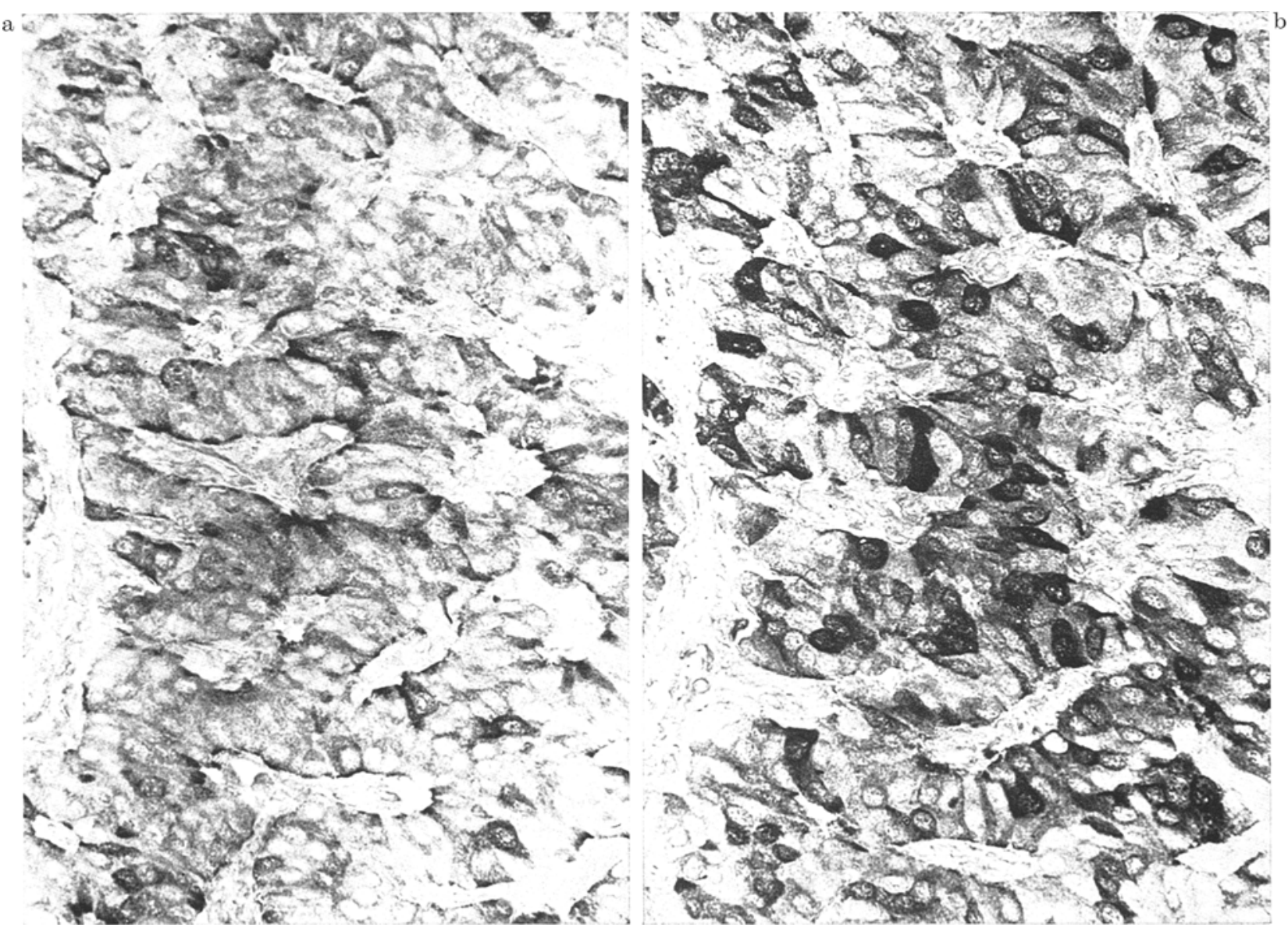

Fig. 4. Comparison between the insulin a) and C-peptide b) stain in the B-cell adenoma (case 10 of Table 1). Same area in consecutive serial sections. After incubation with an anti-C-peptide serum a stronger reaction product is seen. Magnification $\times 400$ 
give a strongly positive reaction to insulin antibodies (Fig. 6b).

On evaluating only those tumours, investigated immediately after extirpation (i.e. excluding falsely negative immunohistologic results caused by ageing of the tumour material) a superiority of the immunohistology to the aldehyde-thionin method in demonstrating insulin is apparent. 7 tumours gave a positive immunohistologic reaction; only the carcinoma (case 12 of Table 1) was negative. In contrast, only 6 of the 7 immunohistologically positive cases gave a positive and in addition often very weak aldehyde-thionin stain in some cells.
14 of Table 1) 7 reacted with insulin antiserum but not with glucagon antiserum. The negative reaction of case 12 could be explained by its extremely low IRIconcentration (B-cell carcinoma with numerous liver metastases).

The immunohistologic reaction with insulin antiserum had markedly decreased one year after embedding in 4 tumours (cases 7 to 10 of Table 1). On the other hand, the islets of the adjacent pancreas reacted with an insulin antiserum after one year and later as strongly as immediately after extirpation of the tumour. This suggests, that the immunohistologic reaction of insulin in B-cell tumours, but not in normal islet

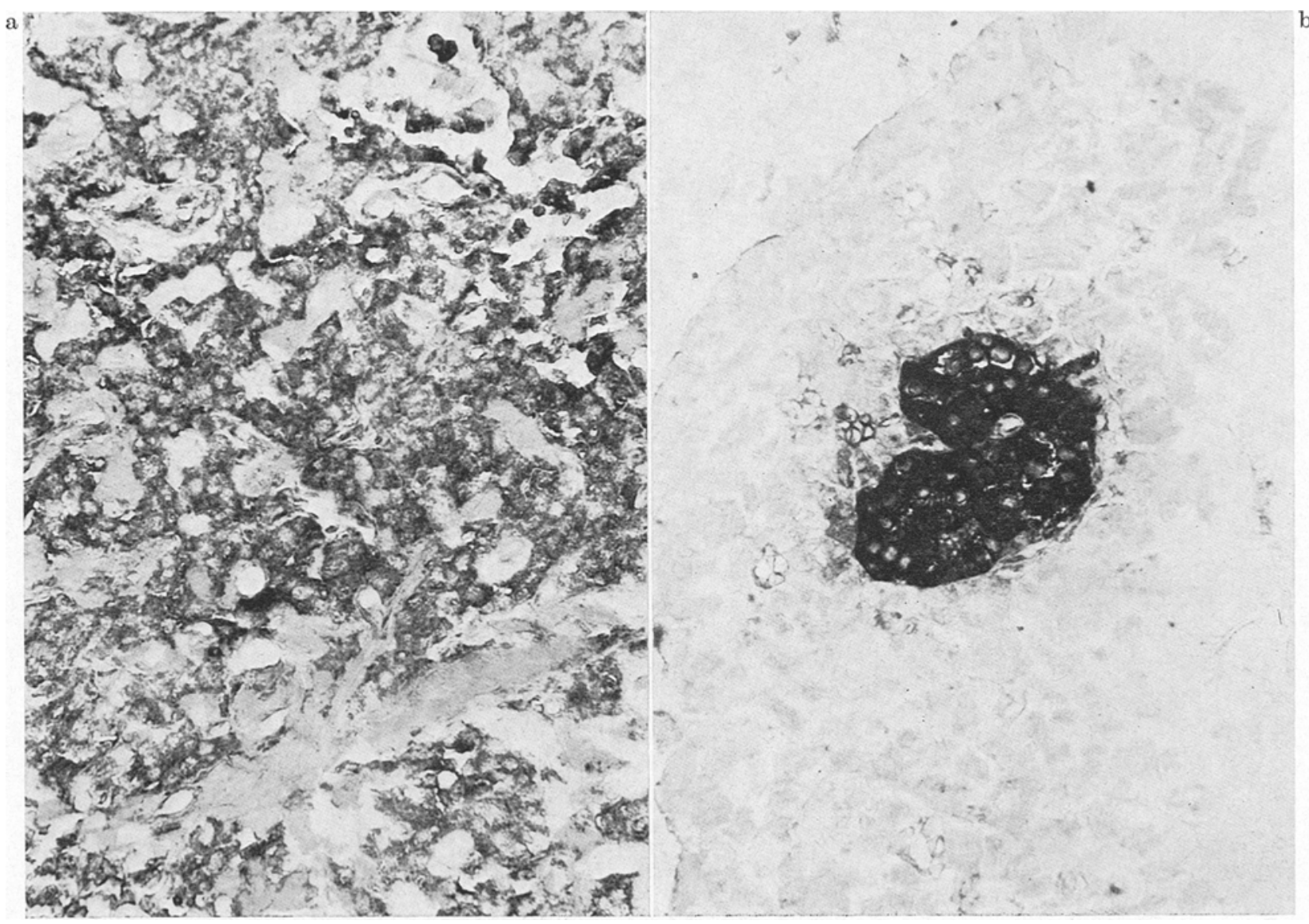

Fig. 5. Immunohistologic demonstration of insulin in the tumour a) and in an islet of the adjacent pancreas b) one year after extirpation. Same case as in Fig. 2. Compared with Fig. 2 a, the intensity of reaction decreases in the tumour one year after extirpation and embedding in paraffin, but not in the adjacent pancreas. Magnification $\times 400$

\section{Discussion}

In contradiction to several authors $[4,9,10,11,14$ 19] who were unable to demonstrate insulin immunohistologically in human B-cell tumours our findings were positive in most insulinomas fixed in Bouin's solution and embedded in paraffin. Of 8 tumours investigated immediately after extirpation (cases 7 to tissue, depends on the time elapsed between the paraffin embedding and the immunohistologic examination. This conclusion is supported by the findings on B-cell tumours investigated immunohistologically for the first time 1 to 4 years after paraffin embedding. In this group only one tumour (case 1 of Table 1) had a low IRI concentration, which could explain the negative reaction, while 5 tumours (cases 2 to 6 ) had a high IRI 
concentration. Inspite of this, one tumour was immunohistologically negative (case 5) and the others reacted only weakly compared to the strong reaction in the islets of the adjacent pancreas of the same cases.

Thus two factors may be responsible for a negative immunohistologic finding in insulinomas: first an unusually low concentration of insulin and secondly an "ageing" of the paraffin embedded material. In addition the method of fixation is important. Tumour tissue fixed in Bouin's solution (after $60 \mathrm{~min}$ or $11 \mathrm{~h}$ ) gave a positive immunohistologic reaction, while tissue fixed in Karnovsky's solution did not react. However, normal B-cells, i.e. the B-cells in the islets differences between the normal and the tumour insulin. Radioimmunochemically the tumour insulin is indistinguishable from normal human insulin. In all our patients elevated IRI levels were found in the plasma and in the tumour extracts. Smith, cited by Lacy [11], did not find differences in the amino acid composition of the $\mathrm{A}$ and $\mathrm{B}$ chain of insulin extracted from several insulinomas.

However, similar observations have been made recently with the immunohistologic demonstration of glucagon-producing cells of the islets of Langerhans and of the intestinal mucosa [20]. Glucagon-producing cells may be stained by labelled antibodies in Boxin,

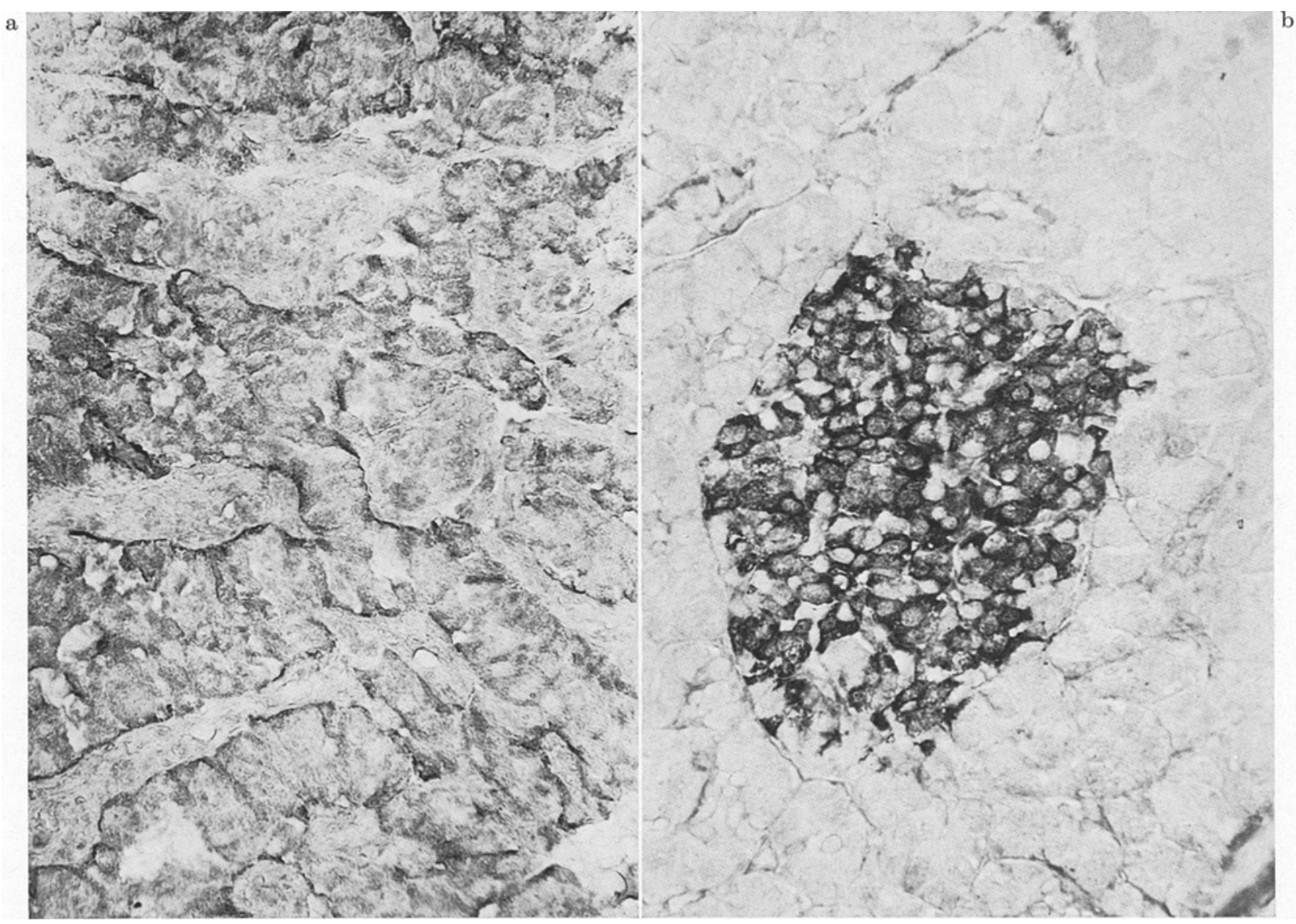

Fig. 6. a) Immunohistologic demonstration of insulin in a B-cell adenoma 4 years after embedding in paraffin (case 3 of Table 1). Only a faint stain is seen. Magnification $\times 400$. b) Immunohistologic demonstration of insulin in an islet of Langerhans 4 years after embedding in paraffin. Unchanged strong positive reaction (case 3 of Table 1). Magnification $\times 400$

of Langerhans of the adjacent pancreas were stained even after fixation in Karnorsky's solution.

According to these findings the normal B-cells differ in two aspects from the tumour B-cells: first they do not loose their reactivity with insulin antiserum, if embedded in paraffin and kept for up to four years; secondly they react with insulin antiserum even after fixation in Karnovsky's solution. This suggests some
Carnoy or formalin fixed normal pancreas [3, 17], but not in the intestinal mucosa fixed by the same methods. This is surprising, because intestinal and pancreatic glucagon can be assayed radioimmunochemically with the same antibody [23]. However, after the fixation of intestinal mucosa with carbodiimide successful demonstration of glucagon has been achieved [20]. Apparently only the carbodiimide fixed enteroglucagon 
permits the formation of an antigen-antibody reaction, whereas other fixatives obviously block the antibody combining site.

Considerable differences between pancreatic and gut glucagon are known biologically, chemically and radioimmunologically $[6,13,22,24,25]$. This has not been found in the case of human islet and tumour insulin. However, our findings suggest some differences.

The positive reaction of the $B$-cells in the insulinomas and in the normal pancreas also by using an antibody against porcine $\mathrm{C}$-peptide requires further comment. Insulin and C-peptide are retained in the B-cells in equimolar amounts [21]. But since human and porcine C-peptide differ in 8 positions of the amino acid sequence [8], the positive staining reaction in human $\mathrm{B}$-cells after treatment with a porcine $\mathrm{C}$-peptide antibody is surprising. This might suggest, that the immunologic determinants of human and porcine C-peptide are localized on common segments of both polypeptide chains. Therefore, it seems possible, that the porcine C-peptide antibody used in our investigations permits the immunohistologic localization of human C-peptide or other precursors of insulin biosynthesis.

As indicated in Table 1 the staining with aldehydethionin is inferior to the immunohistology in demonstrating insulin-producing cells in the tumours. In contrast to the immunohistology the aldehyde-thionin method does not depend alone on the IRI concentration of an insulinoma. A completely negative or very poor staining reaction may occur in insulinomas which had a high IRI concentration and a strongly positive immunohistologic reaction with insulin antiserum. Ultrastructurally it was seen that aldehyde-thionin negatively but immunohistologically positively reacting B-cells contain only atypical Betangranules, i.e. small electrone dense granules with tightly fitting membranes. On the other hand, all aldehyde-thionin positive tumours contained B-cells with typical Betagranules [1].

Acknowledgements. Seven patients were observed and invostigated in our department and operated by Prof. Dr. H.J. Peiper (Department of Surgery, University of Goettingen). Six patients were investigated preoperatively by Prof. Dr. K. Schwarz and PD Dr. P. Bottermann (II. Department of Medicine, University of Munich) and operated by Prof. Dr. R. Zenker (Department of Surgery, University of Munich). We wish to thank these colleagues for supplying us with the results of preoperative investigations and the tumour material. One patient was examined preoperatively by Prof. Dr. K.F. Weinges (Department of Medicine, University of Homburg/Saar) and then transfered to our hospital for further studies and operation.

We also wish to thank Mrs. B. Hillebrecht and Miss G. Schumann for their technical assistance.

The porcine C-peptide was kindly supplied by Dr. R. Geiger and Dr. H.H. Schöne from the Farbwerke Hoechst AG, Frankfurt-Hoechst.

\section{References}

1. Arnold, R., Creutzfeldt, C., Deuticke, U., Frerichs, H., Track, N., Creutzfeldt, W.: Immunohistological, ultrastructural and biochemical investigations of human insulinomas (abstract). European Association for the Study of Diabetes, 7th Annual Meeting, Southampton 1971. Diabetologia 7, 468 (1971).

2. Breustedt, H.J., Kracht, J.: Immunhistologische Untersuchungen mit Anti-Insulin am Inselorgan. 14. Symp. Dtsch. Ges. Endokrin, pp. 174-177. Berlin-Heidelberg-New York: Springer-Verlag 1968.

3. Cavallero, C., Solcia, E., Vassallo, G., Capella, C., Bussolati, G.: Cytology, cytochemistry and ultrastructure of glucagon secreting cells. Acta diabet. lat. 7, $542-556(1970)$.

4. Federlin, K., Raptis, S., Beyer, J., Pfeiffer, E.F.: Immunhistologische Untersuchungen und der Nachweis von Serum - und Tumor-Insulin beim Insulinom. 15. Symp. Dtsch. Ges. Endokrin, pp. 415-417, Berlin-Heidelberg-New Xork: Springer-Verlag 1969.

5. Graham, R.C., Karnovsky, M.J.: The early stages of absorption of injected horseradish peroxidase in the proximal tubules of mouse kidney: ultrastructural cytochemistry by a new technique. J. Histochem. Cytochern. 14, $291-302$ (1966).

6. Heding, L.G.: Radioimmunological determination of pancreatic and gut glucagon in plasma. Diabetologia $7,10-19$ (1971).

7. Karnovsky, M.J.: A formaldehyde-glutaraldehyde fixative of high osmolarity for use in electron microscopy (abstract). J. cell Biol. 27, 137 A (1965a).

8. Ko, A. S. C., Srnyth, D. G., Markussen, J., Sundby, F.: The amino acid sequence of the C-peptide of human proinsulin. Europ. J. Biochem. 20, 190-199 (1971).

9. Lacy, P.E., Williamson, J.R.: Electron microscopic and fluorescent antibody studies of islet cell adenomas. Anat. Rec. 136, 227-228 (1960).

10. - Electron microscopy of beta cells of pancreas. Amer. J. Med. 31, 851-859 (1961).

11. - The pancreatic beta cell. Structure and function. New Engl. J. Med. 276, 187-195 (1967).

12. Malaisse, W.J., Malaisse-Lague, F., Wright, P.H.: A new method for measurement in vitro of pancreatic insulin secretion. Endocrinology 80, 99-108 (1967).

13. Markussen, J., Sundby, F. : Separation and characterization of glucagon-like immunoreactive components from gut extracts by electro-focusing. Abstracts, XVIIth Colloquium on Proteides of the Biological Fluids, Brugge, Belgium p. $471-474$ (1969).

14. Misugi, K., Howell, S.I., Greider, M.H., Lacy, P.E., Sorenson, G.D.: The pancreatic beta cell. Arch. Path. 89, $97-103(1970)$.

15. Nakane, P.K., Pierce, G.B., Jr.: Enzyme-labelled antibodies: preparation and application for the localization of antigens. J. Histochem. Cytochem. 14, $929-931$ (1966).

16. Nakane, P.K., Pierce, G.B., Jr.: Enzyme-labelled antibodies for the light and electron microscopic localization of tissue antigens. J. cell Biol. 33, 307318 (1967).

17. Okada, N., Takaki, R., Kitagawa, M.: Histological and immunofluorescent studies of origin of glucagon in mammalian pancreas. J. Histochem. Cytochem. 16, $405-409$ (1968).

18. Paget, G. E. : Aldehyde-thionin. A stain having similar properties to aldehyde-fuchsin. Stain Technol. 95, $223-226(1954)$

19. Pfeiffer, E.F.: Die Immunologie des Insulins. Verh. dtsch. Ges. inn. Med. 72, 811-833 (1967).

20. Polak, J.M., Bloom, S., Coulling, I., Pearse, A. G. F.: Immunofluorescent localization of enteroglucagon cells in the gastrointestinal tract of the dog. Gut $\mathbf{1 2}$, $311-316$ (1971). 
21. Rubenstein, A.H., Clark, J.L., Melani, F., Steiner, D.F.: Secretion of proinsulin C-peptide by pancreatic beta cells and its circulation in blood. Nature (London) 224, 697-699 (1969).

22. Samols, E., Tyler, J., Megyesi, C., Marks, V.: Immunochemical glucagon in human pancreas, gut and plasma. Lancet $1966 \mathrm{II}, 727-729$.

23. Unger, R.H., Ketterer, H., Eisentraut, A.M.: Distribution of immunoassayable glucagon in gastro. intestinal tissues. Metabolism 15, 865-867 (1966).

24. - Ohneda, A., Valverde, I., Eisentraut, A.M., Exton, J.: Characterization of the responses of circulating glucagon-like immunoreactivity to intraduodenal and intravenous administration of glucose. J. elin. Invest. 47, 48-65 (1968).

25. Valverde, I., Rigopoulou, D., Exton, J., Ohneda, A.,
Eisentraut, A.M., Unger, R.H.: Demonstration and characterization of a second fraction of glucagon-like immunoreactivity in jejunal extracts. Amer. J. med. Sci. 255, 415-420 (1968).

26. Weller, T.H., Coons, A.H.: Fluorescent antibody studies with agents of varicella and herpes zoster pro. pagated in vitro. Proc. Soc. exp. Biol. (N.Y.) 86, $789-794$ (1954).

Dr. R. Arnold

Dr. U. Deuticke

PD Dr. H. Frerichs

Prof. Dr. W. Creutzfeldt

Medizinische Universitätsklinik

D-34 Göttingen

Humboldtallee 1

Federal Republic of Germany 